\title{
$\mathrm{R}^{\text {juenal }} \mathrm{ECHSVINDING}$
}

\section{ALTERNATIF MODEL ANALISIS PERATURAN PERUNDANG-UNDANGAN}

(Alternative of Rule and Regulation Analysis Model)

\author{
Rachmat Trijono \\ Badan Pembinaan Hukum Nasional Kementerian Hukum dan HAM RI \\ Jl. Mayjend Sutoyo - Cililitan Jakarta Timur \\ Email: Ikpi.179@gmail.com
}

Naskah diterima: 7 Desember 2012; revisi: 12 Desember 2012; disetujui: 14 Desember 2012

\begin{abstract}
Abstrak
Sampai saat ini terdapat banyak alat (tools) untuk menganalisis peraturan perundang-undangan, antara lain model RIA, model ROCCIPI, model RegMap, model MAPP dan lain-lain. Namun demikian masing-masing model tersebut mempunyai kelemahan. Untuk itu diperlukan model alternatif yang lebih efektif. Hal inilah yang mendorong untuk diadakan penelitian Research and Development (R\&D), yakni rangkaian proses atau langkah-langkah dalam rangka mengembangkan suatu produk baru atau menyempurnakan produk yang telah ada agar dapat dipertanggungjawabkan. Penelitian menghasilkan produk berupa model baru yang terdiri dari Rule, Affair of Religion, Capacity, Hour, Material, dan Technik. Model ini merupakan alat yang dapat digunakan untuk menguji peraturan perundang-undangan yang sudah ada, dan juga sekaligus untuk mem-filter peraturan perundang-undangan yang akan dibuat.

Kata kunci: analisis, peraturan perundang-undangan, tool model, R\&D

\section{Abstract}

There are a lot of tools to analyze the rules and regulations, including RIA model, ROCCIPI model, RegMAP model, MAPP model and others. However, each model has a drawback. Therefore need another effective alternative model. It push the writer to make a research by Research and Development method, which is a series of processes or steps in order to develop a new product or improving an existing product in order to be accounted for. The product of this research is a new model consisting of a Rule, Affair of Religion, Capacity, Hour, Materials, and Technical. This model is a tool that can be used to test the rule and regulation that already exist, and also to filter the rule and regulation will be made.

Keywords: analysis, rules and regulations, tool model, Research and Development
\end{abstract}




\section{A. Pendahuluan}

Indonesia mendeklarasikan diri sebagai negara hukum. Hal ini sebagaimana dituangkan di dalam Pasal 1 ayat (3) Undang Undang Dasar Negara Republik Indonesia Tahun 1945, yang menentukan bahwa negara Indonesia adalah negara hukum. Menurut Philipus M. Hadjon, dalam suatu negara hukum, mengharuskan adanya pengakuan normatif dan empirik terhadap prinsip supremasi hukum, yaitu bahwa semua masalah diselesaikan dengan hukum sebagai pedoman tertinggi. Dengan demikian dalam suatu negara hukum segala kehidupan, baik kehidupan bernegara, kehidupan berbangsa, maupun kehidupan bermasyarakat harus didasarkan pada hukum. Hal ini memberikan makna bahwa segala tindakan harus didasarkan atas peraturan perundang-undangan yang sah dan tertulis. Peraturan perundang-undangan tersebut harus ada dan berlaku terlebih dulu atau mendahului perbuatan yang dilakukan. ${ }^{1}$ Suatu peraturan perundang-undangan yang baik, menurut Bagir Manan, setidaknya didasari pada 3 (tiga) hal, yakni: a) dasar yuridis (juridishe gelding); b) dasar sosiologis (sociologische gelding); dan c) dasar filosofis. ${ }^{2}$

Saat ini terdapat banyak alat (tools) untuk menganalisis peraturan perundang-undangan, antara lain model RIA, model ROCCIPI, model RegMap, model MAPP dan lain-lain. Semua model memiliki tujuan yang sama, yakni agar peraturan-perundang-undangan yang dianalisis dan yang akan dibentuk menjadi peraturan perundang-undangan yang baik dan efektif.
Namun demikian masing-masing model tersebut mempunyai kelemahan. Model RIA memiliki kelemahan: prosedur yang relatif rinci memerlukan pelatihan khusus bagi penggunanya, terutama untuk memadukan antara pendekatan kualitatif dengan kuantitatif; untuk melaksanakan RIA atas satu peraturan membutuhkan waktu yang relatif cukup lama, sehingga tidak praktis untuk melakukan pemetaan dan analisis atas jumlah regulasi yang cukup banyak; memerlukan pembenahan dari sisi kelembagaan secara fundamental dan harus dipimpin langsung oleh Kepala Pemerintahan; memerlukan keberanian untuk mereformasi sistem regulasi nasional. Kelemahan model RegMAP antara lain hasilnya akan sangat tergantung pada reviewer (tergantung SDM); RegMap baru diuji cobakan pada satu bidang industri, belum diterapkan pada sektor lainnya; tidak user friendly, membutuhkan waktu untuk mengoperasikan "tool"-nya. Kelemahan model ROCCIPI bahwa metode ini lebih efektif dalam proses penyusunan peraturan perundangundangan, namun belum tentu efektif dalam proses mereview peraturan perundangan yang sudah ada. Sedangkan kelemahan model MAPP antara lain memerlukan kejelasan kewenangan; belum adanya kesamaan pemahaman tentang urgensi dan metode dalam rangka reformasi regulasi; dan tingkat pengetahuan dan keterampilan yang tidak sama pada SDM, baik pada tingkat Pusat maupun Daerah.

Untuk itu diperlukan model alternatif yang lebih efektif. Hal inilah yang mendorong untuk diadakan penelitian Research and Development $(R \& D)$.

Philipus M. Hadjon, Perlindungan Hukum Bagi Rakyat di Indonesia; Sebuah Studi Tentang Prinsip-prinsipnya, Penerapannya oleh Pengadilan Dalam Lingkungan Peradilan Umum dan Pembentukan Peradilan Administrasi Negara (Surabaya: Bina Ilmu, 1972).

2 Bagir Manan, Dasar-dasar Perundang-undangan Indonesia (Jakarta: Ind-Hill. Co, 1992), hlm. 13-18. 


\section{$\mathrm{R}^{\text {juenal }} \mathrm{ECHSVINDING}$}

\section{B. Permasalahan}

Permasalahan yang ditelitiadalah bagaimana model analisis peraturan perundang-undang yang efektif? Hal ini penting mengingat bahwa sampai saat ini banyak model analisis peraturan perundang-undangan yang masing masing mempunyai kelebihan dan kekurangan.

Produk dari penelitian ini diharapkan dapat memberikan alternatif model analisis peraturan perundang-undangan yang lebih efektif, yakni yang dapat digunakan untuk menganalisis peraturan perundang-undangan yang sudah ada maupun untuk membentuk peraturn yang belum ada.

\section{Metode Penelitian}

Penelitian ini menggunakan metode Penelitian dan Pengembangan atau Research and Development (R\&D) yakni rangkaian proses atau langkah-langkah dalam rangka mengembangkan suatu produk baru atau menyempurnakan produk yang telah ada agar dapat dipertanggungjawabkan. Produk tersebut tidak selalu berbentuk benda atau perangkat keras (hardware), sepertibuku, modul, alatbantu pembelajaran di kelas atau di laboratorium, tetapi bisa juga perangkat lunak (software), seperti program komputer untuk pengolahan data, pembelajaran di kelas, perpustakaan atau laboratorium, ataupun model-model pendidikan, pembelajaran, pelatihan, bimbingan, evaluasi, sistem manajemen, dan lain-lain. ${ }^{3}$
Penelitian ini menggunakan langkah yang ditempuh Borg dan Gall, yaitu: ${ }^{4}$ Studi Pendahuluan, Merencanakan Penelitian, Pengembangan Desain, Preliminary Field Test, Revisi Hasil Uji Lapangan Terbatas, Main Field Test, Revisi Hasi Uji Lapangan Lebih Luas, Uji Kelayakan, Revisi Final Hasil Uji Kelayakan, Desiminasi dan Implementasi Produk Akhir.

Data kualitatif yang terkumpul dianalisis menggunakanmetodeMilesdanHuberman ${ }^{5}$ yang dilakukan secara interaktif dan dilakukan secara terus menerus sampai tuntas, sehingga datanya sudah jenuh. Aktivitas dalam analisis data yaitu: reduksi data, penyajian data, dan kesimpulan. Mereduksi data berarti merangkum, memilih hal-hal yang pokok, memfokuskan pada hal-hal yang penting.

Tujuan utama penelitian ini adalah pertama, menghasilkan produk berupa model dan kedua, menguji keefektifan evaluasi tersebut. ${ }^{6}$ Namun dalam kesempatan ini penulis hanya menghasilkan produk saja, belum sampai pada pengujian efektifitas model.

\section{Pembahasan}

\section{Beberapa Model Analisis Regulasi}

\section{a. Regulatory Impact Analysis (RIA)}

Metode analisa Regulatory Impact Analysis (RIA) yaitu suatu alat fundamental untuk menilai dampak regulasi. RIA digunakan untuk menguji dan mengukur kemungkinan manfaat, biaya

Anonim, Pendekatan, Jenis, dan Metode Penelitian Pendidikan: Kompetensi Penelitian dan Pengembangan (Jakarta: Direktorat Tenaga Kependidikan Direktorat Jenderal Peningkatan Mutu Pendidikan dan Tenaga KependidikanKementerian Pendidikan Nasional, 2008), hlm. 50.

Meredith D. Gall, Joyce P. Gall, dan Walter R. Borg, Educational Research: An Introduction (Boston: Pearson Education ,Inc., 2007), hlm. 589.

5 Sugiyono, Metode Penelitian Kuantitatif Kualittif dan R\&D (Bandung: Alfabeta, 2011), hlm. 297.

$6 \quad$ Ibid., 246. 
dan efek dari peraturan baru atau yang sudah ada. $^{7}$

RIA menggunakan 10 pertanyaan yang merupakan standar baku yang ditetapkan oleh OECD, yaitu: ${ }^{8}$

1) Apakah masalahnya didefinisikan dengan benar?

Masalah yang akan dipecahkan harus dinyatakan secara tepat, memberikan bukti dari sifat dan besarnya, dan menjelaskan mengapa hal tersebut muncul (mengidentifikasi entitas insentif yang terkena). ${ }^{9}$

2) Apakah tindakan pemerintah sudah tepat? Intervensi pemerintah harus didasarkan pada bukti eksplisit bahwa tindakan pemerintah dibenarkan, mengingat sifat dari masalah, kemungkinan manfaat dan biaya tindakan (berdasarkan penilaian yang realistis efektivitas pemerintah), dan mekanisme alternatif untuk mengatasi masalah.

3) Apakah regulasi merupakan tindakan terbaik pemerintah?

Pada awal proses regulasi, regulator harus melakukan perbandingan berbagai instrumen kebijakan baik peraturan maupun nonperaturan, berdasarkan masalah-masalah yang relevan seperti biaya, manfaat, efek distribusi dan persyaratan administrasi. ${ }^{10}$

4) Apakah peraturan ada dasar hukumnya?

Proses peraturan harus terstruktur sehingga semua keputusan peraturan ketat menghormati "rule of law"; itu adalah, tanggung jawab harus jelas untuk memastikan bahwa semua peraturan yang diperkenankan oleh peraturan tingkat yang lebih tinggi dan konsisten dengan kewajiban perjanjian internasional, dan sesuai dengan prinsip-prinsip hukum yang relevan seperti kepastian, proporsionalitas dan persyaratan prosedural yang berlaku. ${ }^{11}$

5) Berapa tingkatan birokrasi pemerintah yang dilibatkan untuk koordinasi regulasi ini? Regulator harus memilih tingkat yang paling tepat dari pemerintah untuk mengambil tindakan, atau jika ada beberapa tingkatan yang terlibat, harus merancang sistem yang efektif koordinasi antara tingkat pemerintahan. ${ }^{12}$

6) Apakah regulasi bermanfaat dibanding biayanya?

Regulator harus memperkirakan total biaya dan manfaat yang diharapkan dari setiap peraturan usulan dan alternatif, dan harus membuat perkiraan tersedia dalam format yang dapat diakses para pengambil keputusan. Biaya tindakan pemerintah harus dapat dibenarkan oleh manfaat sebelum tindakan diambil. ${ }^{13}$

7) Apakah distribusi di masyarakat dampaknya akan transparan?

Sejauh distributif dan nilai-nilai ekuitas dipengaruhi oleh intervensi pemerintah, regulator harus membuat transparan peraturan distribusi biaya dan manfaat di kelompok-kelompok sosial. ${ }^{14}$

OECD, Building an Institutional Framework for Regulatory Impact Analysis: Guidance for Policy Maker, (2008), hlm. 14.

Ibid., hlm. 12-14.

Ibid., hlm. 12.

Ibid., hlm. 13.

Ibid.

Ibid.

Ibid.

14 Ibid. 
8) Apakah peraturan tersebut jelas, konsisten, dipahami dan diakses oleh pengguna?

Regulator harus menilai apakah peraturan akan mungkin dipahami oleh pengguna, dan untuk itu harus mengambil langkah-langkah untuk memastikan bahwa struktur teks dan aturan sejelas mungkin. ${ }^{15}$

9) Apakah semua pihak yang berkepentingan memiliki kesempatan yang sama untuk menyampaikan pandangan mereka?

Peraturan harus dikembangkan secara terbuka dan transparan, dengan prosedur yang tepat yang efektif dan tepat waktu masukan dari pihak-pihak yang tertarik seperti bisnis yang terkena dampak dan serikat buruh, kelompok-kelompok kepentingan lainnya, atau tingkat pemerintahan lainnya ${ }^{16}$.

10) Bagaimana kepatuhan terhadap regulasi dapat dicapai?

Regulator harus menilai insentif dan lembaga-lembaga melalui peraturan yang akan berlaku, dan harus merancang strategi pelaksanaan tanggap yang membuat penggunaan terbaik dari mereka. ${ }^{17}$

\section{b. Regulatory Mapping (RegMap)}

Metode RegMAP mengadopsi proses RIA, oleh karena itu elemen-elemen utama analisa RIA diterapkan untuk mengembangkan metodemetode penyaringan (filtering), yakni: ${ }^{18}$
- Aplikasi dari sejumlah pernyataan yang berbasis RIA seperti: tujuan, substansi, dan perkiraan dampak dari sebuah regulasi;

- Penggunaan berbagai metode konsultasi (focus group discussion/FGD, survey perusahaan dan narasumber/pakar) untuk membantu mengidentifikasi dan mengkaji regulasi-regulasi yang kemungkinan bermasalah.

Fiter pertama merupakan 5 (lima) pertanyaan kunci RIA yang meliputi legalitas, redundansi, tujuan peraturan, dampak ekonomi dan kekhawatiran pemangku kepentingan. ${ }^{19}$

Tujuan Filter kedua adalah untuk menilai kualitas dari setiap peraturan yang keluar dari

1 Filter. ${ }^{20}$ Kualitas regulasi didefinisikan dalam hal: ${ }^{21}$

Apakah tujuan regulasi didefinisikan dengan jelas dan baik dibenarkan;

Apakah peraturan tersebut sebanding dengan masalah kebijakan yang ditangani;

- Apakah peraturan tersebut ditargetkan untuk masalah kebijakan yang akan ditangani dan mencapai tujuan kebijakan dengan beban minimum pada mereka yang terkena dampak;

- Apakah manfaat bersih peraturan tersebut lebih besar daripada biaya bersih.

Kelima dimensi kualitas regulasi tersebut dieksplorasi dalam Filter 2 melalui penggunaan 10 pertanyaan (yaitu, pernyataan yang membutuhkan jawaban 'ya' atau 'tidak'), ${ }^{22}$ 
dan filter ke 3 (tiga) merupakan stakeholder consultation yang dapat dilakukan dengan FGD (Focus Group Discussion). ${ }^{23}$

\section{c. Metode ROCCIPI (Rule, Opportunity, Communication, Interest, Process, and (deology)}

Ann, Robert Siedman dan Nalin Abeysekere ${ }^{24}$ mengintrodusir metodologi Problem Solving dengan menggunakan alat ukur yang dikenal dengan ROCCIPI. ${ }^{25}$ Alat ukur ini merupakan instrumen untuk mengidentifikasi problem sosial yang timbul sebagai akibat dari pemberlakuan peraturan perundang-undangan.

1) Rule (peraturan):

a) Susunan kata dari peraturan kurang jelas atau rancu;

b) Peraturan mungkin memberi peluang perilaku masalah;

c) Tidak menangani penyebab-penyebab dari perilaku bermasalah;

d) Memberi peluang pelaksanaan yang tidak transparan, tidak bertanggung jawab, dan tidak partisipatif; dan

e) Memberikan kewenangan yang tidak perlu kepada pejabat pelaksana dalam memutuskan apa dan bagaimana mengubah perilaku bermasalah.

2) Opportunity (Kesempatan):

a) Apakah lingkungan di sekeliling pihak yang dituju suatu undang memungkinkan mereka berperilaku sebagaimana diperintahkan undang-undang atau tidak? b) Apakah lingkungan tersebut membuat perilaku yang sesuai tidak mungkin terjadi?

3) Capacity (kemampuan):

a) Apakah para pelaku peran memiliki kemampuan berperilaku sebagaimana ditentukan oleh peraturan yang ada?

b) Berperilaku sebagaimana ditetapkan oleh undang-undang yang ada.

4) Communication (komunikasi):

Ketidaktahuan seorang pelaku peran tentang undang-undang mungkin dapat menjelaskan mengapa dia berperilaku tidak sesuai. Apakah pihak yang berwenang telah mengambil langkah-langkah yang memadai untuk mengkomunikasikan peraturanperaturan yang ada kepada para pihak yang dituju? Tidak ada orang yang dengan secara sadar mematuhi undang-undang kecuali bila dia mengetahui perintah.

5) Interest (kepetingan):

Apakah ada kepentingan material atau non material (sosial) yang mempengaruhi pemegang peran dalam bertindak sesuai atau tidak sesuai dengan aturan yang ada?

6) Process (proses):

Menurut kriteria dan prosedur apakah - dengan proses yang bagaimana - para pelaku peran memutuskan untuk mematuhi undang-undang atau tidak? Biasanya, apabila sekelompok pelaku peran terdiri dari perorangan, kategori "proses" menghasilkan beberapa hipotesa yang berguna untuk menjelaskan perilaku mereka. Orang-orang

Ibid.

24 Ann Seidman, Robert B. Seidman dan Nalis Abeyserkere, Penyusunan Rancangan Undang Undang Dalam Perubahan Masyarakat Yang Demokrtis: Sebuah Panduan Untuk Pembuat Rancangan Undang Undang, (Indonesia dan USAID: Elips II, 2001), hlm.117.

25 Ibid., bahwa urutan kategori-kategori dalam daftar isian ROCCIPI tidak penting; urutan kategori-kategori tersebut semata-mata hanya untuk membuat akronim guna memudahkan para penyusun rancangan undangundang mengingatnya. 


\section{$\mathrm{R}^{\text {juknal }}$ ECHSVINDING}

biasanya memutuskan sendiri apakah akan mematuhi peraturan atau tidak.

7) Ideology (ideologi):

Apakah nilai-nilai, kebiasaan dan adatistiadat yang ada cukup mempengaruhi pemegang peran untuk bertindak sesuai atau bertentangan dengan aturan yang ada?

\section{d. Model Analisa Peraturan Perundang- undangan (MAPP)}

MAPP adalah sebuah alat untuk melakukan reviu/evaluasi regulasi yang diindikasikan bermasalah atau berpotensi bermasalah. Operasionalisasi MAPP diawali dengan inventarisasi regulasi, identifikasi dan klasifikasi regulasi yang bermasalah atau berpotensi bermasalah, dan dilanjutkan dengan analisis regulasi. Analisis regulasi tersebut menghasilkan 3 (tiga) pilihan keputusan tindakan, yaitu: (1) regulasi dipertahankan; (2) regulasi direvisi; dan (3) regulasi dicabut. Dari keputusan tersebut kemudian dibuat suatu rencana aksi dalam bentuk rencana tindak. ${ }^{26}$

Gambar 1. Operasionalisasi MAPP

\section{TAHAPAN REVIUIEVAUASI REGULASI}

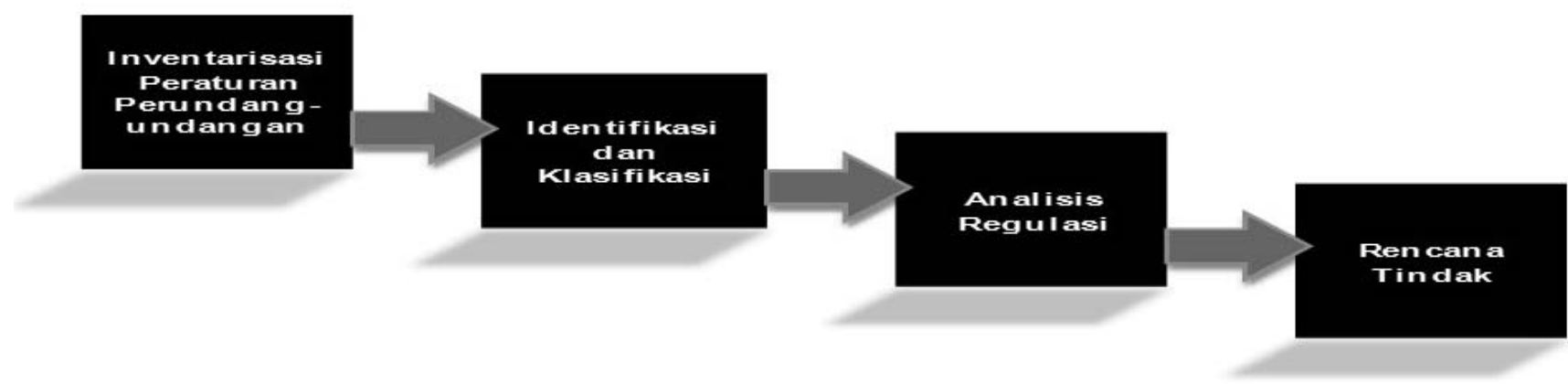

Sumber: Direktorat Analisa Peraturan Perundang-undangan Kementerian Perencanaan

Pembangunan Nasional/ Badan Perencanaan Pembangunan Nasional

Tabel. 1 Inventarisasi Peraturan Perundang-undangan

SKPD

\begin{tabular}{|c|c|c|c|c|c|}
\hline No & NOMOR REGULASI & NAMA REGULASI & STATUS & SKPD TERKAIT & KETERANGAN \\
\hline & & & & & \\
\hline & & & & & \\
\hline & & & & & \\
\hline
\end{tabular}

Sumber: Direktorat Analisa Peraturan Perundang-undangan Kementerian Perencanaan

Pembangunan Nasional/ Badan Perencanaan Pembangunan Nasional

26 Direktorat Analisa Peraturan Perundang-undangan, Reformasi Regulasi Dalam Rangka Mendukung Upaya Pencapaian Prioritas Pembangunan Nasional dan Daerah, (Palembang: Juni 2012). 


\section{$\mathrm{R}^{\text {juknaL }}$ ETSVINDING}

Media Pembinaan Hukum Nasional

Volume 1 Nomor 3, Desember 2012

Tabel 2. Identifikasi dan Klasifikasi

\begin{tabular}{|c|c|c|c|c|}
\hline NO. & KETENTUAN PASAL & POTENSI MASALAH & URAIAN MASALAH & SKPD TERKAIT \\
\hline \multirow{4}{*}{1.} & & LEGALITAS & & \\
\hline & & Konfilik & & \\
\hline & & Inkonsisten & & \\
\hline & & Duplikasi & & \\
\hline \multirow{5}{*}{2} & & Multi tafsir & & \\
\hline & & Tidak Operasional & & \\
\hline & & KEBUTUHAN & & \\
\hline & & Masyarakat & & \\
\hline & & Penyelenggara Negara & & \\
\hline \multirow{5}{*}{3} & & RAMAH & & \\
\hline & & Mudah dipahami \& dilaksanakan & & \\
\hline & & Ramah biaya & & \\
\hline & & Ramah persyaratan & & \\
\hline & & Ramah proses & & \\
\hline \multicolumn{5}{|c|}{ 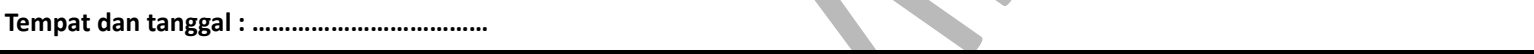 } \\
\hline \multicolumn{2}{|c|}{ NAMA } & & \multicolumn{2}{|l|}{ TANDA TANGAN } \\
\hline \multicolumn{3}{|c|}{. } & & \\
\hline \multicolumn{3}{|c|}{ JABATAN } & & \\
\hline
\end{tabular}

Sumber: Direktorat Analisa Peraturan Perundang-undangan Kementerian Perencanaan Pembangunan Nasional/ Badan Perencanaan Pembangunan Nasional

Tabel 3. Analisis Pemangku Kepentingan

\begin{tabular}{|l|l|l|l|l|}
\hline No. & KETENTUAN PASAL & ANALISIS & TOLAK UKUR & KETERANGAN \\
\hline 1. & & LEGALITAS & & \\
\hline 2. & & KEBUTUHAN (NEEDS) & & \\
\hline 3. & & RAMAH (FRIENDLI) & & \\
\hline NAMA: & & JABATAN: & TANDA TANGAN: \\
\hline
\end{tabular}

Sumber: Direktorat Analisa Peraturan Perundang-undangan Kementerian Perencanaan Pembangunan Nasional/ Badan Perencanaan Pembangunan Nasional 


\section{$\mathrm{R}^{\text {juknal }}$ ECHSVINDING}

Media Pembinaan Hukum Nasional

Tabel 4. Konsolidasi Analisis

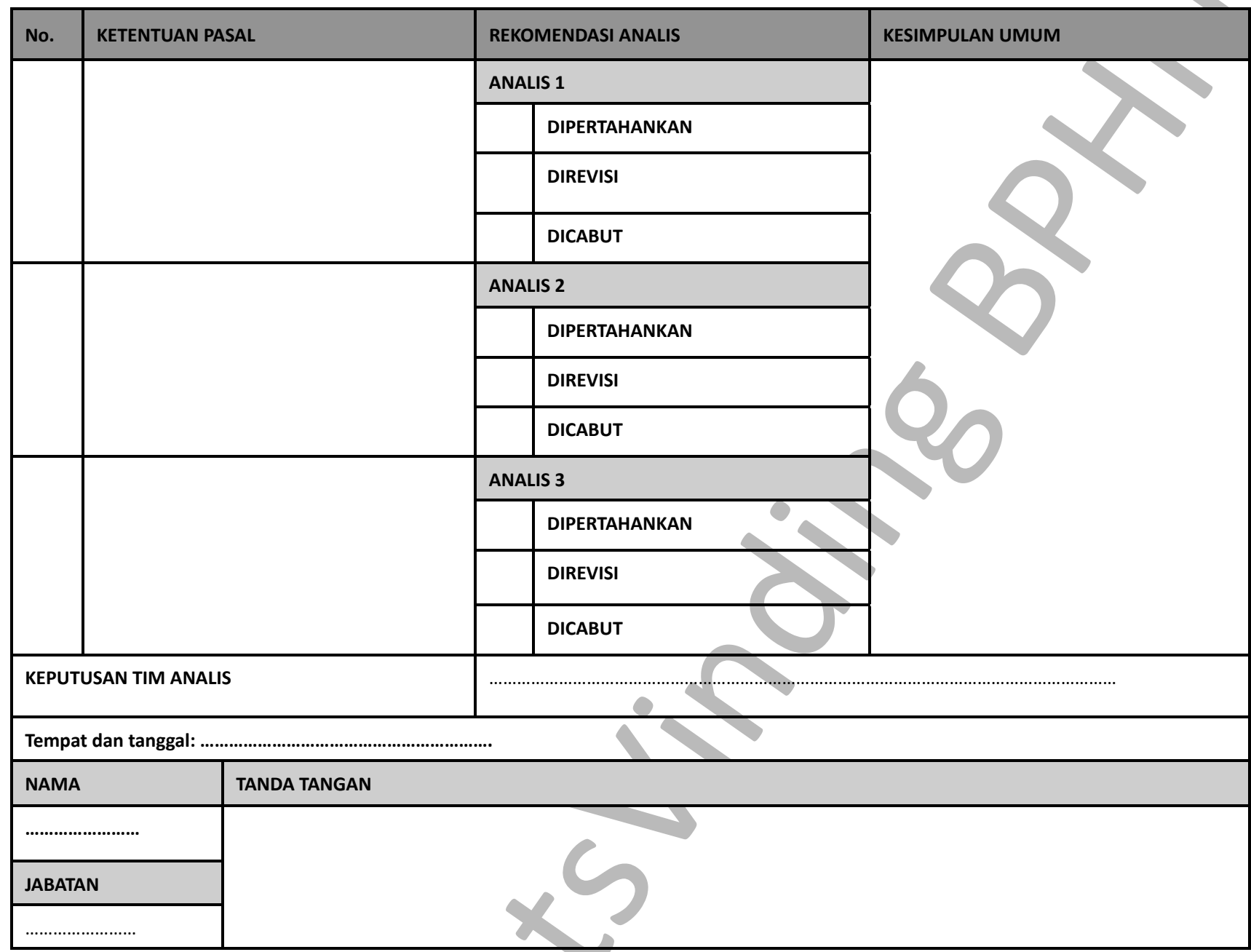

Sumber: Direktorat Analisa Peraturan Perundang-undangan Kementerian Perencanaan

Pembangunan Nasional/ Badan Perencanaan Pembangunan Nasional

Tabel 5. Rencana Tindak

\begin{tabular}{|l|l|l|l|c|c|c|c|}
\hline No & REGULASI & ANALISA PERMASALAHAN & $\begin{array}{c}\text { KEPUTUSAN } \\
\text { TINDAKAN }\end{array}$ & $\begin{array}{c}\text { STRATEGI } \\
\text { PENYELESAIAN }\end{array}$ & $\begin{array}{c}\text { WAKTU } \\
\text { PELAKSANAAN }\end{array}$ & SKPD TERKAIT & $\begin{array}{c}\text { TINDAK } \\
\text { LANJUT }\end{array}$ \\
\hline & & & & & & \\
\hline
\end{tabular}

Sumber: Direktorat Analisa Peraturan Perundang-undangan Kementerian Perencanaan

Pembangunan Nasional/ Badan Perencanaan Pembangunan Nasional

Rencana tindak regulasi adalah suatu rencana aksi yang berisi langkah-langkah konkrit sebagai upaya mengatasi peraturan perundang-undangan yang diindikasikan atau berpotensi bermasalah serta menghambat upaya pencapaian prioritas pembangunan nasional. Rencana tindak regulasi berbentuk tabel tentang rencana tindak regulasi sesuai dengan bidang dan prioritas pembangunan yang akan dilakukan. Rencana tindak regulasi memuat kolom-kolom tentang: 
1) Peraturan dalam bidang/sektor tertentu yang diindikasikan menghambat pencapaian prioritas pembangunan nasional

2) Analisa/permasalahan

3) Upaya yang dilakukan

4) Strategi penyelesaian

5) Waktu Pelaksanaan

6) $\mathrm{K} / \mathrm{L}$ terkait

7) Tindak lanjut/Rekomendasi

\section{Pengembangan Desain}

Hasil penelitian menciptakan model baru yang merupakan gabungan dari beberapa model anlisis peraturan perundang-undangan. Model ini merupakan alat yang dapat digunakan untuk menguji peraturan perundang-undangan yang sudah ada, dan juga sekaligus untuk mem-filter peraturan perundang-undangan yang akan dibuat. Alat ini berisi instrumen yang harus diikuti oleh para penguji dan pembuat peraturan perundang-undangan. Namun dalam tulisan ini penulis belum mencantumkan instrumen tersebut. Pada dasarnya model ini terdiri dari 7 (tujuh) unsur, yakni Rule, Affair of Religion, Capacity, Hour, Material, dan Technik.

\section{a. Rule}

Berarti bahwa peraturan yang dibuat tidak boleh bertentangan dengan Pancaasila dan UUD 1945. Untuk tidak bertentangan dengan Pancasila, maka patokan yang wajib diikuti mengacu pada butir-butir Pancasila, yakni sila Ketuhanan Yang Maha Esa: (1) Bangsa Indonesia menyatakan kepercayaannya dan ketaqwaannya terhadap Tuhan Yang Maha Esa. (2) Manusia Indonesia percaya dan taqwa terhadap Tuhan Yang Maha Esa, sesuai dengan agama dan kepercayaannya masing-masing menurut dasar kemanusiaan yang adil dan beradab. (3) Mengembangkan sikap hormat menghormati dan bekerjasama antara pemeluk agama dengan penganut kepercayaan yang berbeda-beda terhadap Tuhan Yang Maha Esa. (4) Membina kerukunan hidup di antara sesama umat beragama dan kepercayaan terhadap Tuhan Yang Maha Esa. (5) Agama dan kepercayaan terhadap Tuhan Yang Maha Esa adalah masalah yang menyangkut hubungan pribadi manusia dengan Tuhan Yang Maha Esa. (6) Mengembangkan sikap saling menghormati kebebasan menjalankan ibadah sesuai dengan agama dan kepercayaannya masing-masing. (7) Tidak memaksakan suatu agama dan kepercayaan terhadap Tuhan Yang Maha Esa kepada orang lain.

Sila Kemanusiaan Yang Adil dan Beradab: (1) Mengakui dan memperlakukan manusia sesuai dengan harkat dan martabatnya sebagai makhluk Tuhan Yang Maha Esa. (2) Mengakui persamaan derajad, persamaan hak dan kewajiban asasi setiap manusia, tanpa membeda-bedakan suku, keturrunan, agama, kepercayaan, jenis kelamin, kedudukan sosial, warna kulit dan sebagainya. (3) Mengembangkan sikap saling mencintai sesama manusia. (4) Mengembangkan sikap saling tenggang rasa dan tepa selira. (5) Mengembangkan sikap tidak semena-mena terhadap orang lain. (7) Menjunjung tinggi nilai-nilai kemanusiaan. (8) Gemar melakukan kegiatan kemanusiaan. (9) Berani membela kebenaran dan keadilan. (10) Bangsa Indonesia merasa dirinya sebagai bagian dari seluruh umat manusia. (11) Mengembangkan sikap hormat menghormati dan bekerjasama dengan bangsa lain.

Sila Persatuan Indonesia: (1) Mampu menempatkan persatuan, kesatuan, serta kepentingan dan keselamatan bangsa dan negara sebagai kepentingan bersama di atas kepentingan pribadi dan golongan. (2) 


\section{$\mathrm{R}_{\text {EECHTS }}^{\text {juknal }}$ INDING

Sanggup dan rela berkorban untuk kepentingan negara dan bangsa apabila diperlukan. (3) Mengembangkan rasa cinta kepada tanah air dan bangsa. (4) Mengembangkan rasa kebanggaan berkebangsaan dan bertanah air Indonesia. (5) Memelihara ketertiban dunia yang berdasarkan kemerdekaan, perdamaian abadi dan keadilan sosial. (6) Mengembangkan persatuan Indonesia atas dasar Bhinneka Tunggal Ika. (7) Memajukan pergaulan demi persatuan dan kesatuan bangsa.

Sila Kerakyatan yang Dipimpin oleh Hikmat Kebijaksanaan dalam Permusyawaratan/ Perwakilan: (1) Sebagai warga negara dan warga masyarakat, setiap manusia Indonesia mempunyai kedudukan, hak dan kewajiban yang sama. (2) Tidak boleh memaksakan kehendak kepada orang lain. (3) Mengutamakan musyawarah dalam mengambil keputusan untuk kepentingan bersama. (4) Musyawarah untuk mencapai mufakat diliputi oleh semangat kekeluargaan. (5) Menghormati dan menjunjung tinggi setiap keputusan yang dicapai sebagai hasil musyawarah. (6) Dengan i'tikad baik dan rasa tanggung jawab menerima dan melaksanakan hasil keputusan musyawarah. (7) Di dalam musyawarah diutamakan kepentingan bersama di atas kepentingan pribadi dan golongan. (8) Musyawarah dilakukan dengan akal sehat dan sesuai dengan hati nurani yang luhur. (9) Keputusan yang diambil harus dapat dipertanggungjawabkan secara moral kepada Tuhan Yang Maha Esa, menjunjung tinggi harkat dan martabat manusia, nilai-nilai kebenaran dan keadilanmengutamakan persatuan dan kesatuan demi kepentingan bersama. (10) Memberikan kepercayaan kepada wakil-wakil yang dipercayai untuk melaksanakan pemusyawaratan.

Sila Keadilan Sosial Bagi Seluruh Rakyat Indonesia: (1) Mengembangkan perbuatan yang luhur, yang mencerminkan sikap dan suasana kekeluargaan dan kegotongroyongan. (2) Mengembangkan sikap adil terhadap sesama. (3) Menjaga keseimbangan antara hak dan kewajiban. (4) Menghormati hak orang lain. (5) Suka memberi pertolongan kepada orang lain agar dapat berdiri sendiri. (6) Tidak menggunakan hak milik untuk usaha-usaha yang bersifat pemerasan terhadap orang lain. (7) Tidak menggunakan hak milik untuk halhal yang bersifat pemborosan dan gaya hidup mewah. (8) Tidak menggunakan hak milik untuk bertentangan dengan atau merugikan kepentingan umum. (9) Suka bekerja keras. (10) Suka menghargai hasil karya orang lain yang bermanfaat bagi kemajuan dan kesejahteraan bersama. (11) Suka melakukan kegiatan dalam rangka mewujudkan kemajuan yang merata dan berkeadilan sosial.

Disamping ada kesesuaian dengan Pancasila, juga harus ada kesesuaian dengan UUD 1945. Hal ini penting mengigat bahwa pada tahun 2012 pengujian undang-undang yang dikabulkan Mahkamah Konstitusi meningkat yakni sebesar 30,9 persen dibanding tahun sebelumnya yang hanya sekitar 22,3 persen. Mahkamah Konstitusi sepanjang tahun 2012 telah menerima 169 perkara pengujian undang-undang sebanyak 169 yang terdiri dari 51 perkara sisa 2011 dan 118 perkara yang diterima tahun 2011. Pada 2012 Mahkamah Konstitusi telah memutus sebanyak 97 perkara, di mana amar putusannya dikabulkan 30 perkara (30,9 persen), 31 perkara ditolak (31,9 persen), 30 perkara tidak diterima (30,9 persen) dan enam ditarik kembali oleh pemohonnya (6,1 persen). Sedangkan pada 2011 sebanyak 145 perkara PUU yang terdiri dari 51 sisa 2010 dan 86 perkara yang diterima. Mahkamah Konstitusi pada 2011 telah memutus 94 perkara pengujian undang-undang dengan 
amar putusan 21 perkara dikabulkan (22,3 persen), 29 perkara ditolak (30,8 persen), 35 tidak diterima (37,2 persen) dan sembilan perkara ditarik kembali pemohonnya $(9,5$ persen). Meningkatnya prosentase pembatalan undang-undang ini karena menunjukkan masih ada norma undang-undang yang bermasalah atau bertentangan dengan UUD 1945. Ada tiga unsur yang meletarbelakangi sebuah undangundang dinyatakan bertentangan dengan konstitusi. Pertama, adanya tukar-menukar kepentingan antara pembuat undang-undang. Kedua, sikap tidak profesional pembuat undangundang. Ketiga, terjadi perubahan situasi. ${ }^{27}$

Salah satu keharusan adanya kesesuaian dengan UUD 1945 adalah keharusan adanya kewenangan dari pembuat peraturan perundang-undangan. Setiap peraturan perundang-undangan harus dibuat oleh badan atau pejabat yang berwenang. Kalau tidak, peraturan perundang-undangan itu batal demi hukum (van rechtswegenietig). Dianggap tidak pernah ada dan segala akibatnya batal secara hukum. Misalnya, undang-undang dalam arti formal (wet in formelezin) dibuat oleh Presiden dengan persetujuan DPR. Setiap undang-undang yang tidak merupakan produk besama antara Presiden dan DPR adalah batal demi hukum. Begitu pula Keputusan Menteri, Peraturan Daerah dan sebagainya harus pula menunjukkan kewenangan pembuatnya. Kedua, keharusan adanya kesesuaian bentuk atau jenis peraturan perundang-undangan dengan materi yang diatur, terutama kalau diperintahkan oleh peraturan perundang-undangan tingkat lebih tinggi atau sederajat. Ketidak sesuaian bentuk ini dapat menjadi alasan untuk membatalkan peraturan perundang-undangan tersebut. Misalnya kalau UUD 1945 atau undang-undang terdahulu menyatakan bahwa sesuatu diatur dengan undang-undang, maka hanya dalam bentuk undang-undang hal itu diatur. Kalau diatur dalam bentuk lain misalnya Keputusan Presiden, maka Keputusan Presiden tersebut dapat dibatalkan (vernietigbaar). Ketiga, keharusan mengikuti tata cara tertentu. Apabila tata cara tersebut tidak diikuti, peraturan perundang-undangan mungkin batal demi hukum atau tidak/belum mempunyai kekuatan hukum mengikat. Peraturan Daerah dibuat oleh Kepala Daerah dengan persetujuan DPRD. Kalau ada Peraturan Daerah tanpa (mencantumkan) persetujuan DPRD maka batal demi hukum. Dalam undang-undang tentang pengundangan (pengumuman) bahwa setiap undang-undang harus diundangkan dalam Lembaran Negara sebagai satu-satunya cara untuk mempunyai kekuatan mengikat. Selama pengundangan belum dilakukan, maka undang-undang tersebut belum mengikat. Keempat, keharusan tidak bertentangan dengan peraturan perundangundangan yang lebih tinggi tingkatannya. Suatu undang-undang tidak boleh mengandung kaidah yang bertentangan dengan UUD. Demikian pula seterusnya sampai pada peraturan perndangundangan tingkat lebih bawah.

\section{b. Affair of Religion}

Peraturan perundang-undangan tidak boleh bertentangan dengan agama apapun yang diakui di Indonesia. Berdasarkan Penetapan Presiden (Penpres) No.1/PNPS/1965 junto

27 Ditjend PP, "MK: 2012 Prosentase Pembatalan UU Meningkat", http://ditjenpp.kemenkumham.go.id/beritahukum-dan-perundang-undangan/2366-mk-2012-prosentase-pembatalan-uu-meningkat.html, (diakses 28 Januari 2012). 


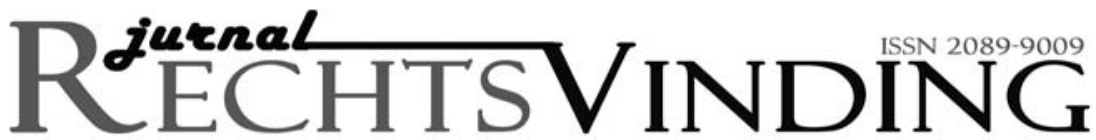 \\ Media Pembinaan Hukum Nasional}

Undang-undang No.5/1969 tentang Pencegahan Penyalahgunaan dan Penodaan agama dalam penjelasannya pasal demi pasal dijelaskan bahwa Agama-agama yang dianut oleh sebagian besar penduduk Indonesia adalah: Islam, Kristen, Katolik, Hindu, Buddha, dan Konghucu.

\section{c. Capacity}

Peraturan perundang-undangan harus dapat dilaksanakan subyek hukum.

\section{d. Hour}

Peraturan perundang-undangan yang efektif harus tepat waktu. Dengan demikian jangan sampai timing-nya kurang tepat.

\section{e. Material}

Isi atau substansi dari peraturan perundangundangan sudah harus diteliti, dan dikaji. Untuk itu harus ${ }^{28}$ ada Naskah Akademisnya. ${ }^{29}$ Materi muatan peraturan perundang-undangan mencerminkan kenyataan yang hidup dalam masyarakat. Dalam satu masyarakat industri, peraturan perundang-undangannya harus sesuai dengan kenyataan-kenyataan yang ada dalam masyarakat industri tersebut. Kenyataan itu dapat berupa kebutuhan atau tuntutan atau masalah-masalah yang dihadapi seperti masalah perburuhan, hubungan majikan-buruh, dan lain sebagainya.

\section{f. Tehnik}

Pembentukan peraturan perundangundangan yang baik tidak lepas dari teknik pembuatan peraturan perundang-undangan yang baik. Jika teknik pembuatan peraturan perunang-undangan tidak baik, maka ada kemungkinan untuk dibatalkan. Kerangka peraturan perundang undangan terdiri dari:

1) Judul

2) Pembukaan yang terdiri dari: frasa DENGAN RAHMAT TUHAN YANG MAHA ESA, jabatan pembentukperaturan perundang-undangan, konsiderans, dan dasar hukum, diktum.

3) Batang tubuh yang terdiri dari ketentuan umum, materi pokok yang diatur, ketentuan pidana (jika diperlukan), ketentuan peralihan (jika diperlukan), dan ketentuan penutup.

4) Penutup

5) Penjelasan (jika diperlukan), dan

6) Lampiran (jika diperlukan)

\section{E. Penutup}

Model analisis peraturan perundang-undang yang efektif adalah Rule, Affair of Religion, Capacity, Hour, Material, dan Technik. Namun demikian, penelitian ini baru sampai tahap menghasilkan 'model' sebagai alternatif untuk menganalisis peraturan perundang-undangan. Untuk itu perlu dilanjutkan untuk uji efektiitas model yang telah dihasilkan tersebut.

28 Undang-Undang Nomor 12 Tahun 2011 tentang Pembentukan Peraturan Perundang-undangan Pasal 43 ayat (3) menentukan bahwa Rancangan Undang-Undang yang berasal dari DPR, Presiden, atau DPD harus disertai Naskah Akademik.

29 Ibid., Pasal 1 angka 11 menentukan bahwa Naskah Akademik adalah naskah hasil penelitian atau pengkajian hukum dan hasil penelitian lainnya terhadap suatu masalah tertentu yang dapat dipertanggungjawabkan secara ilmiah mengenai pengaturan masalah tersebut dalam suatu Rancangan Undang-Undang, Rancangan Peraturan Daerah Provinsi, atau Rancangan Peraturan Daerah Kabupaten/Kota sebagai solusi terhadap permasalahan dan kebutuhan hukum masyarakat. 


\section{DAFTAR PUSTAKA}

\section{Buku}

Gall, Meredith D., Joyce P. Gall, dan Walter R. Borg, Educational Research: An Introduction (Boston: Pearson Education, Inc., 2007).

Hadjon, Philipus M., Perlindungan Hukum Bagi Rakyat di Indonesia; Sebuah Studi Tentang Prinsip-prinsipnya, Penerapannya oleh Pengadilan Dalam Lingkungan Peradilan Umum dan Pembentukan Peradilan Administrasi Negara (Surabaya: Bina Ilmu, 1972).

Manan, Bagir, Dasar-dasar Perundang-undangan Indonesia, (Jakarta: Ind-Hill. Co, 1992).

OECD, Building an Institutional Framework for Regulatory Impact Analysis: Guidance for Policy Maker, (2008).

Seidman, Ann, Robert B. Seidman dan Nalis Abeyserkere, Peenyusunan Rancangan Undang Undang Dalam Perubahan Masyarakat Yang Demokrtis: Sebuah Panduan Untuk Pembuat Rancangan Undang Undang, (Indonesia dan USAID: Elips II, 2001), hlm.117.

Sugiyono, Metode Penelitian Kuantitatif Kualittif dan $R \& D$ (Bandung: Alfabeta, 2011).

USAID dan SEMADA, Regmap: Institutionalizing Regulatory Reform in Indonesia: summary report, (DAl, Maret 2009).
Makalah / Artikel / Prosiding / Hasil Penelitian Anonim, Pendekatan, Jenis, dan Metode Penelitian Pendidikan: Kompetensi Penelitian dan Pengembangan (Jakarta: Direktorat Tenaga Kependidikan Direktorat Jenderal Peningkatan Mutu Pendidikan dan Tenaga Kependidikan Kementerian Pendidikan Nasional, 2008).

Direktorat Analisa Peraturan Perundang-undangan, Reformasi Regulasi Dalam Rangka Mendukung Upaya Pencapaian Prioritas Pembangunan Nasional dan Daerah, (Palembang: Juni 2012)

\section{Internet}

Ditjend PP, MK: 2012 Prosentase Pembatalan UU Meningkat, http://ditjenpp.kemenkumham. go.id/berita-hukum-dan-perundangundangan/2366-mk-2012-prosentasepembatalan-uu-meningkat.html, diakses tgl 28 Januari 2012.

\section{Peraturan}

Undang-Undang Nomor 12 Tahun 2011 tentang Pembentukan Peraturan Perundang-undangan.

Undang-Undang Nomor 5 Tahun 1969 tentang Pernyataan Berbagai Penetapan Presiden Dan Peraturan Presiden Sebagai Undang-Undang.

Penetapan Presiden Nomor 1/PNPS/1965 tentang Pencegahan Penyalahgunaan dan/atau Penodaan Agama. 